\title{
Better Life Through Science!
}

Kee-Wan Chang

Professor, Chonbuk National University Graduate School of Dentistry

Academic journals are principal publishing media for scientific research papers from various academic fields. While reading a journal article - I do not remember when and in which journal -, I came across the phrase cited in the title. The purpose of science cannot be clearly defined as we define a physical concept. This phrase, however, personally appealed greatly to me.

I have of course read other articles. A professor with a career spanning over 20 years is estimated to have written between 100 and 150 papers. Quite true! As mine numbers some 120, it may well reach 130 by the time I retire.

However, why do we write papers? The first answer that occurs to me, perhaps not the brightest one, is to take up writing to fulfill a certain sense of responsibility. This is true for a great number of my papers. As a matter of fact, I do not remember many occasions where I wrote for my own satisfaction based on research topic dictated by my heart. In other words, most papers were written as part of the process of providing guidance to my graduate school students or for the purpose of climbing higher rungs in my career path.

Looking back on the first years of my life as a professor, I had the satisfaction of selecting research subjects to my heart's desire, and I published papers on the results of these studies. Driven by my earnest desire to keep studying, I aimed to pursue a continued study abroad program as soon as possible to consolidate my academic capacity to conduct valuable research. One day, during the course of my third year as a professor, my goal to live this type of pure academic life was suddenly challenged by the pressure from the university to mentor graduate school students. Because graduate school students were only assigned to professors with strong academic accomplishments and background power, my modest wish was to only mentor graduate school students after completing my studies abroad. It was the 1980s, a period in which the social system was somewhat authoritarian, and the academic world was no exception.

After exhausting all conceivable sorts of escape maneuvers, this professor who was at his wits' end started to mentor graduate school students. Once placed in an inevitable situation, my instinct to do my utmost in any task entrusted to me kicked in. I spent countless hours contemplating appropriate research themes for my students to support their dissertations, thinking that students only rarely enter the graduate school with a dissertation topic already decided. I was quite empathetic, so to speak.

Surrounded by graduate school students, I have lived a busy life determining the directions of dissertations and guiding the students through their dissertations. As byproducts (?) of this busy life, the number of papers carrying my name as the corresponding author has increased.

The time has now arrived to appraise my work!

For what reasons did I publish specific types of papers?

Just as the reasons for living change as the times change, there seems to be an increasing number of papers written for research fund reports or professorial performance evaluations. There is of course nothing wrong with this approach, but it may be a good idea to from time to time stop and contemplate why we write papers. This approach might allow us to enter retirement without regrets. 


\title{
Better Life Through Science!
}

장기완

\author{
전북대학교 치의학전문대학원 교수
}

학회지는 기본적으로 여러 과학적 연구에 대한 결과물로써 논문을 싣는 서책이다.

언제가 어느 책인지 모르지만, 제목의 구절을 읽은 적이 있다. 과학의 목적이 물리학의 정의처럼 딱히 정해진 것은 없는 것 같다. 그러나 나에게는 이 말이 개인적으로 아주 마음에 든다.

또 다른 글도 읽었다. 20 년 이상 교수생활을 한 사람이라면 통상 100 편에서 150 편 정도의 논문을 쓴다고 한다. 그래! 나도 이제까지 120 여 편 정도 되니까... 앞으로 정년퇴임까지 계속 논문을 쓰면 한 130 여 편 되지 않을까? 하는 생각이 든다.

그런데, 우리는 왜 논문을 쓰는 것일까? 어리석은 나의 머리에 첫 번째 드는 생각은 어떤 의무감 같은 것에서 출발하는 경우 가 많았고, 정말로 내가 연구 해보고, 나 자신을 위하여 쓴 논문은 적은 것 같다. 즉, 대학원생 지도과정에서 발생하는 결과물로 써 논문이나, 교수 자신의 승급을 하는데 필요한 논문이 많은 것 같다.

나의 교수 생활 초기를 돌아보자. 교수 생활 초기에는 정말로 내가 연구하고 싶은 것만을 연구하고 이를 논문으로 발표하였 다. 따라서 공부를 더 해보고 싶은 마음에 어서 빨리 해외연수를 다녀오고 능력을 배양하여 좋은 연구를 하여보자고 하였다. 이 렇게 살기를 원하였지만, 교수가 된 지 3년쯤 되는 어느 날 갑자기 학교 당국에서 대학원생을 받으라고 상당한 강요(?)를 하였 다. 이제까지는 대학에서 소위 힘 있는 사람(?)만이 대학원생을 배정받고 있었기에, 나는 적어도 해외연수 이후에 대학원생을 받기를 희망했었다. 이때가 1980 년대이었고, 이 시기의 사회체재란 약간은 권위적 분위기가 있었고, 이는 대학도 마찬가지였 다.

이리 저리 빼다가 힘없는 교수는 하는 수 없이 대학원생을 배정받았다. 성격상 책임이 생기면 기본적으로 열심히 하는 편이 어서(?), 이들의 학위 논문을 지도하는 과정에 어떤 과제를 부여할까 고민하였다. 대학원이 입학 때 자신의 학위논문 주제를 가 지고 오는 경우는 극히 드물다고 생각하니까... 느낌 아니까......

대학원생이 생긴 이후로는 거의 대학원생의 학위논문 방향설정, 지도 등으로 바쁘게 살았고, 이의 결과물로 교신저자의 위 치로 많은 논문이 생겼다.

자, 이제 평가해보자!

나는 어떤 이유로, 어떤 성격의 논문을 발표하였는가?

시대에 따라, 사는 이유가 달라지듯이, 요즈음에는 연구비보고서를 위하여, 혹은 교수업적평가를 위하여 작성하는 논문이 많 은 것 같다. 이것이 나쁜 것은 아니지만, 가끔은 왜 논문을 쓰는지 돌이켜보는 것도 장차 정년퇴임을 할 때쯤 후회가 없지 않을까? 